Text published by: KRIEF, S., HLADIK, C.M. \& HAXAIRE, C. (2005) - Ethnomedicinal and bioactive properties of plants ingested by wild chimpanzees in Uganda. Journal of Etnopharmacology, 101: 1-15.

\title{
Ethnomedicinal and bioactive properties of plants ingested by wild chimpanzees in Uganda
}

\author{
Sabrina Krief (a,b), Claude Marcel Hladik (a)*, Claudie Haxaire (c)
}

(a) USM 0104, Eco-Anthropologie et Ethnobiologie, Département Hommes, Natures, Sociétés, Muséum National d'Histoire Naturelle, 43 rue Buffon, 75231 Paris Cedex 05, France.

(b) USM 0502, Chimie et Biochimie des Substances Naturelles, Département Régulations, Développement, Diversité Moléculaire, Muséum National d'Histoire Naturelle, 63 rue Buffon, 75231 Paris Cedex 05, France.

(c) CESAMES (UMR 81-36 ParisV/CNRS/INSERM), Centre de Recherche Psychotropes, Santé Mentale, Société, Université René Descartes, 45 rue des Saints-Pères, 75270 Paris cedex 06

et Département de Sciences Humaines et Sociales, Faculté de médecine et des sciences de la santé, Brest, France.

Key-words : Zoopharmacognosy; Ethnomedicine; Ethnoveterinary medicine; Pan troglodytes; Apes diet; Uganda

* corresponding author

E-mail : cmhladik@mnhn.fr; tel.+33(0)160479220; fax.+33(0)160465719

\begin{abstract}
Wild chimpanzees eat several plant species claimed by traditional healers to cure diseases. However, the behaviour leading apes to ingest these peculiar species is not clearly understood. Some of the items consumed by chimpanzees have low nutritional value, and there is a growing body of evidence suggesting that health might be improved or regulated by such ingestion. Observations concerning the diet and the health condition of wild chimpanzees (Pan troglodytes schweinfurthii) in the Kibale National Park (Uganda) are discussed in relation to the ethnomedicinal utilization of plant species reviewed in literature. Among the 163 plant parts known to be eaten by these chimpanzees, at least 35 (21.4\%) are used in traditional medicine as treatments for intestinal parasites, skin infections, reproduction and respiratory diseases. Relationships with pharmacological properties are presented, taking into account the difficulties of interpreting ethnomedicinal data. In conclusion, a greater knowledge of ape's behaviour and health may provide a new complementary method to select plants for biomedical research.
\end{abstract}

\section{Introduction}

The long-term observations carried out during the two last decades on the Kanyawara chimpanzee (Pan troglodytes schweinfurthii) community in Kibale National Park, Uganda (R.W. Wrangham, pers. com.) as well as our recent data show that, among items rarely eaten by chimpanzees, some plant parts are used as medicine by African traditional healers. In order to draw attention to the potential therapeutic value of plants considered as dietary items for chimpanzees, a review of ethnomedicinal and pharmacological properties of these peculiar plant parts is presented together with recent data on plant consumption by ill chimpanzees. 
In wild plants, the secondary compounds, not directly involved in plant physiology, are considered as resulting from the selective pressure exerted by microbes and phytophagous invertebrates and vertebrates, providing protection from predators and pathogens. Ironically such non-nutritional metabolites, generally toxic or inhibiting consumption by reducing palatability or digestibility, are the major source of drugs for humans in western medicine. The limit between poison and medicine is often based on the dose. Moreover, a growing body of evidence shows that animals such as insects, birds and primates use plant parts with secondary compounds to improve their comfort or their health (Clark and Russel Masson, 1985; 1988; Fauth et al., 1991; Gwinner et al., 2000; Danburry et al., 2000; Karban and English-Loeb, 1997; Baker, 1996).

During the last decades, detailed information about plants eaten by great apes have been obtained (e.g. Schaller, 1963; Reynolds and Reynolds, 1965; Hladik, 1977b; Wrangham, 1977; Rodman, 1978; Tutin and Fernandez, 1993) and several studies were focused on how primates cope with secondary compounds in their diet (Hladik, 1977a; Oates et al., 1977; Glander, 1982; Wrangham and Waterman, 1983). The ingestion of non-nutritional plant parts, such as bark, and some unusual behaviours - namely bitter pith chewing and whole leaves swallowing- associated with biological activities of the plants consumed were also observed (e.g. Huffman and Seifu, 1989; Ohigashi et al., 1994; Wrangham, 1995), supporting the hypothesis suggested by Janzen (1978), that plant secondary compounds actually help animals to combat or control diseases.

Concerning human health and medicine, the empirically deeply rooted knowledge and wisdom of native people were considered as a useful pre-screen in the search of plants of pharmacological interest (Holmstedt, 1991), and was emphasized when the Bureau of American Ethnology started the investigations on medicinal ethnobotany. Farnsworth, in 1990, highlighted the importance of higher plants as source of drugs: Among 119 drugs used in allopathic medicine extracted from 90 species of plants, about $75 \%$ of these were discovered by chemists attempting to identify the active compounds in relation to ethnomedicinal uses. In 1985, it has been estimated that about $64 \%$ of the world population utilize plants as medicine (Farnsworth et al., 1985).

However, results of ethnopharmacological surveys are not easily discerned since local people's and researchers' perspectives (emic and etic categories) rarely overlap. In our view, a drug, according to the concept prevailing in our industrialized western societies, differs from that of food, although ethnological data show large differences, in various ethnic groups. For instance, a "drug" such as the powder of dried leaves of Erythroxylum coca, used in Amazonia by Tukano Indians (Hugh-Jones, 1993), might be considered closer to the food category by the consumers, even though it is never consumed during a meal. Tukanos do swallow, after chewing, the leaf powder, which has an actual nutritional value (316 kcal and $15.6 \mathrm{~g}$ of protein $/ 100 \mathrm{~g})$. Similarly, the fruits of Cola nitida eaten in tropical Africa are structurally classified as food rather than drug among the Gouro (Haxaire, 1996). Even in our western societies, the limits can be blurred, and some pharmaceuticals such as benzodiazepines could be considered as food by some consumers (Helman, 1981). Moreover, in some instances, food and drug categories explicitly overlap. Etkin and Ross (1983) suggested the concept of "Food as medicine and medicine as food" after taking into account the indigenous knowledge. They wrote «We draw inspiration from the Hausa term for medecine 'magani', a concept so inclusive that it signifies 'plants administered to cure fever' as well as 'foods used to remedy hunger'». These authors also show that, among the 35 indigenous plant species commonly used by the Hausa in the treatment of one or more symptoms of malaria infection, 31 (89\%) are also used in a dietary context. In vitro assays of therapeutic efficacy and oxidative processes have been conducted (Etkin, 1981; Etkin and Ross, 1983) supporting the hypothesis that some of these plants may have preventive and/or therapeutic value in malaria infection. In such contexts, a pharmacologist who attempts to reach physical efficiency from that kind of inquiries should be aware of the blurred limits of the notions of illness and medication.

Could the observation of the feeding behaviour of a close relative of Homo sapiens living in a natural setting provide a complementary approach? Some striking similarities between plants ingested by chimpanzees and used in ethnomedicine have already been underlined (Huffman et al., 1996; 1998; Cousins and Huffman, 2002; Huffman, 2003) and new detailed information is presented here, further suggesting that the study of animal behaviour might be a promising lead for identification of potentially bioactive plants. 


\section{Materials and methods}

\subsection{Study site}

The observations were conducted in the Kibale National Park, located in Uganda, between $0^{\circ} 13$ 'to $0^{\circ} 41^{\prime} \mathrm{N}$ and $30^{\circ} 19^{\prime}$ to $30^{\circ} 22^{\prime} \mathrm{E}$. The elevation is between 800 and $1500 \mathrm{~m}$, and the rainfall averages $1700 \mathrm{~mm}$ per year. Vegetation of this mid-altitude moist forest also includes secondary forest, grassland, swamps and plantations of Eucalyptus and pines, and elements of lowland tropical rainforest.

\subsection{Behavioural and veterinary observations of chimpanzees}

The habituated community of chimpanzees (Pan troglodytes schweinfurthii), including about 50 individuals, was observed between December 2000 and March 2001, and in October 2001.

Feeding and behavioural data were obtained in 650 hours of observations by recording activities and food ingested in ten-minutes periods, changing observed animal every ten minutes. Ad libitum observations were also carried on during particular sequences related to possible medicative behaviour especially on ill chimpanzees and for ingestion of items that are rarely eaten and/or that appeared most likely non-nutritional (bark). During both the study periods, 46 items corresponding to 35 species were consumed (Krief, 2003). Additional information on feeding behaviour was obtained from a list of 117 food plant species corresponding to 163 food items recorded by Wrangham and his assistants during 15 years of "Kibale Chimpanzee Project" (Wrangham, unpublished data). Health state was monitored daily with non-invasive methods including veterinary observations, urinalysis (76 samples from 32 chimpanzees) and parasite analysis (252 fecal samples from 38 chimpanzees) (Krief et al., 2003; 2005).

\subsection{Plant collection, bioassays, and ethno-medicinal data}

Specimens of twenty-four plant species included in the diet of Kibale chimpanzees were identified first with the help of the field assistants, then compared to herbarium specimens. Voucher specimens (SK1 to SK24) have been deposited at the herbarium of the Museum National d'Histoire Naturelle (Paris, France). Plant material (42 plant parts from the 24 species) was also collected for further chemical analysis, and airdried in the field, sheltered from the sun. The remaining plant samples are stored at the Institut de Chimie des Substances Naturelles, Gif-sur-Yvette.

Dried extracts (84) were assessed for in vitro activities against the following human parasites, presently used in biomedical research, Leishmania donovani, Trypanosoma brucei brucei, Plasmodium falciparum and a free-living worm Rhabditis pseudoelongata with almost the same sensitivity to Ivermectin as a parasite worm. Antitumour activities were assayed by measuring the cytotoxicity against KB cells from human tumour tissue. Extracts were also tested against bacteria (Staphylococcus aureus, Escherichia coli), yeast and fungi (Candida tropicalis, Penicillium crustosum). For detailed description of the protocols, see Krief (2003). Because of the taxonomic proximity of human beings and chimpanzees, compounds active against human pathogens likely inhibit infectious agents affecting chimpanzees.

For the ethnomedicinal data concerning the plants eaten by chimpanzees, the web site 'Prelude' constructed by Baerts and Lehmann (2002), a source of ancient and up-to-date documentation on both traditional human and veterinary medicine, was used in parallel with the search of conventional sources of bibliography.

\section{Results}

As shown in Table I, various parts of 27 plant species from the chimpanzee diet at Kibale, are used as traditional medicine in Africa. That is $23 \%$ of the 117 food species recorded since the beginning of the project. Rate of consumption of various food items (leaf, bark, fruit, stem, pith, etc) was categorized as 'rare', 'common' or 'frequent' according to the long-term observations of R.W. Wrangham (pers. comm.) and the observations of the present study. Among the thirty-five items used in traditional medicine listed in Table I, thirty-one (89\%) are ingested occasionally by Kanyawara chimpanzees. Four items are more commonly ingested : Phytolacca dodecandra fruits, Celtis africana leaves, Pennisetum purpureum stems, Monodora myristica seeds. 
We have screened pharmacological activities of 24 species eaten by chimpanzees, among which ten different items are used in ethnomedicine. Among those, seven items show actual activities. The results are presented in Table II together with bibliographical records showing actual activities of other species eaten by chimpanzees. Most of these plants with bioactive compounds have traditional utilizations as medicine or poison, also reported in Table II. Two plant parts for which we did not find any use in traditional medicine are eaten by chimpanzees and present significant activities namely, Diospyros abyssinica bark and Uvariopsis congensis leaves. The chimpanzees also consumed fruits of Blighia unijugata, leaves and stems of Antiaris toxicaria and bitter tasting berries of Phytolacca dodecandra (containing monodesmosidic triterpenoid saponins) which are reputed for being poisonous and respectively used by local people for fishing, hunting and as molluscicidal agent to prevent schistosomiasis.

According to criteria of western veterinary medicine, most of the chimpanzees observed were in good health during the study periods. Intestinal parasites have been detected in the feces of almost all the individuals studied but the parasitical load was low compared to human standards, with $96 \%$ of the samples containing less than 1000 helminths/g of feces (Krief et al., 2003; 2005). However, at least 10 cases of obviously ill chimpanzees were diagnosed. Bacterial infections were diagnosed in two instances, including one wounded individual and another one suffering from tooth abscess. An old female with an important abdominal distension also had a left hand defect, the swollen hand being not used for tree climbing. Two chimpanzees were detected suffering from gastrointestinal disorders. Five cases were respiratory infections with nasal discharge, sneezing, cough, including two severe cases with lethargy, dyspnea (breathing difficulties) and anorexia. Table I points out that species from the diet of chimpanzees are traditionally used as medicine for such symptoms. For instance, ten of the medicinal plant parts from the table I are used to cure skin diseases or infections, fifteen of them are for digestive disorders. Thirteen species are traditionally used for reproductive health problems and respiratory or circulatory diseases are indications for thirteen plant parts. Finally, twelve species are used to relieve pain or fever.

These wounded or sick chimpanzees were followed carefully in the field. Since the symptoms were totally absent after one week, we consider that all of them had recovered from their respective diseases. The three following examples illustrate utilization of plants with putative activity, according to the ethnomedicinal records reported in Table I.

(1) An adult male chimpanzee whose toe was severely cut after a fight was observed during the week following the injury, ingesting:

- Acanthus pubescens stems, which are used in Burundi against skin infections and dermatosis,

- Ficus capensis fruits, which are used to cure abscess,

- Ficus exasperata leaves, also used for oedema, and for healing abscess, or ulcer (this antiulcerogenic property has been confirmed by in vivo bioassays; see Table II).

(2) Parasitism and digestive disorders were diagnosed in a 6 year-old female. The chimpanzee was the only individual of the group observed ingesting Albizia grandibracteata bark, that was never observed eaten by the other chimpanzees of the group. The bark of this species is used in Uganda and in the Democratic Republic of Congo to alleviate digestive disorder and parasitism. As shown in Table II, our laboratory evaluation of pharmacological properties of plants eaten by chimpanzees demonstrated in vitro anthelminthic activity and cytotoxic properties against KB cells of the A. grandibracteata bark extract. Saponins present in the extract are responsible of such properties (Krief et al., 2004).

(3) A 17 year-old male, was observed frequently coughing, looking weak and lethargic. Sneezing was frequent and discharge was thick with mucous. Faecal samples were rich in parasites. This ill chimpanzee was the single individual from the party to select unripe fruits, although feeding on mature fruits of Ficus capensis is common. In Ivory Coast, the green figs of F. capensis are selected as traditional veterinary medicine.

Actually figs play an important role in the diet of Kanyawara diet. During our study period, 3 species of figs accounted together for more than $40 \%$ of the feeding time. In December 2000 and January 2001, the diet was dominated by the consumption of figs. Beside their nutritive value, figs contain secondary compounds. For instance, ficin is a proteolytic and anthelminthic enzyme related papain, which occurs in the latex of several species of Ficus (Etkin and Ross, 1982). Some of these species (F. capensis, F. thonningii) are included in the chimpanzee diet. We observed some individuals (but not all of them) removing latex before ingesting figs. Ficin, which is harmless to human, is known to digest living intestinal parasites (Etkin and Ross, 1982). 
These examples and the tables illustrate the actual use by the chimpanzees of plants with medicinal properties (according to either traditional knowledge, or pharmacological evidence). Specific plant items generally eaten in small amount in the context of obvious sickness may be involved in recovering of health. Moreover, the chimpanzees regularly ingest a great variety of food plants (i.e. 46 items corresponding to 35 species in four months and at least 163 food items recorded since observed), thus including in their diet most of the plants with bioactive properties that may help in health maintenance and explain the general good health observed (Krief, 2004).

\section{Discussion}

\section{1. Medicines for chimpanzees?}

Globally, the diet of the chimpanzees in Kibale includes several plant species with actual or putative bioactivities, likely to offer medicinal benefits. A low parasitical load has been observed in almost all the individuals of this group (Krief et al., 2003; 2005), that could be related to the consumption of plant parts with anti-parasite properties, six species from their diet being used to treat worms by local practitioners. The permanent access to small amounts of various plants is likely to play a role of 'preventive medication', maintaining a low level of pathogens and a sub-clinical health status, together with climate and altitude. The role of figs in chimpanzees diet and especially in Kanyawara community in period of drupes scarcity has previously been emphasized (Wrangham et al., 1996). As figs are nearly continuously available (Wrangham et al., 1991; Wrangham et al., 1996) and provide a baseline level of metabolizable energy and protein, Conklin and Wrangham (1994) considered that fig pulps have a nutritional value for chimpanzees similar to a staple human food item as potato. Assuming that figs are eaten throughout the year, some compounds that may help in health maintenance or restoration, as ficin but also tannins, pectins and latex may be ingested regularly. As previously suggested by Huffman $(1997 ; 2001)$, a global activity of the plants ingested may provide a balanced diet beneficial to health. This aspect might remind us the 'Mediterranean diet' (Hill \& Giacosa, 1992) recommended for humans beings after epidemiological surveys.

The 'curative medication' is another aspect that can be inferred from the data presented in this paper. Our results provide information completing previous observations on potential self-medicative behaviour notably the two most famous examples namely the ingestion of bitter pith of Vernonia amygdalina (Huffman and Seifu, 1989;Huffman et al., 1993) and the whole leaf swallowing (Wrangham \& Nishida, 1983). Concerning this last behaviour, since the rough leaves of Aspilia spp. covered with bristly trichomes were not masticated by the chimpanzees, a non-nutritional beneficial value was suggested. The hypothesis that the leaves, because of their physical properties, flush of the gastro-intestinal tract is consistent with the observation of the expulsion of the live adult worms of Oesophagostomum along with the leaves (Huffman et al., 1996). Among the observed cases, the consumption of Albizia grandibracteata bark fits this type of medicative behaviour. Although case studies are uncommon, the evidence that sick chimpanzees eat peculiar food items that are not eaten by the healthy individuals of the group rises the issue of specific medication.

One way to detect a bioactive species might be the exceptionality and the small amount of the ingestion. As previously noted, the exposure to active compounds is usually rare and the dose ingested low to avoid toxic side-effect. However, an item might be infrequently consumed because of the low availability, unpleasant side-effect of the consumption, or the unpalatability of the item. For the bark, which is available all around the year, but non-nutritional, fibrous and requiring time and energy to be stripped off from the trunk, the ingestion might be related to other specific criteria. Similarly, the Trichilia rubescens leaf-consumer eats in rare occasions only few leaves at a time, picking them one by one and leaving the shrub with most leaves unconsumed. In this last instance, we were not able to diagnose any symptoms of illness in the chimpanzees eating these leaves. Nevertheless, the peculiar behaviour suggesting that the T. rubescens consumer have different criteria of selection that the other individuals of the group led us to discover two new compounds, Trichirubines A and B that are strongly active against Plasmodium falciparum (Trichirubine A IC $50=0.3 \mu \mathrm{g} / \mathrm{ml}$ ) in the leaves of T. rubescens (Krief et al., 2004).

What could determine such a complex behaviour? Food intake is generally mediated by unconscious conditioning mechanisms (Hladik and Simmen, 1996). What has been called 'chimpanzee cultures' (Wrangham et al., 1994) includes many skills such as termites fishing, nut breaking that are learned by a young individual in the context of a social group. Further investigations would be necessary to infer in such specific plant choices a different way of learning including individual or social learning. 


\section{2. What can be learned from the ethnomedicinal data?}

There is a growing evidence that ethno-medicine is an efficient source of new pharmaceuticals (Farnsworth, 1990; Fellows, 1992). This approach using ethno-botany and folk medicine can provide useful information as a pre-screen to select plant for experimental studies but data from literature should be cautiously examined for the following reasons:

(1)Traditional medicines are based on a non-dualistic perception of human beings. The activity of a remedy is understood, in the cultural context, according to specific alteration of body and soul, which characterizes the illness. Even though the practical result of medication is biologically demonstrated, remedies, from the lay people point of view, are necessarily linked to endogenous cultural significance (Augé, 1986). These interpretations rarely correspond with what is implied in the practice of western medicine (or biomedicine). For these reasons, information and interpretation of symptoms in ethno-medicinal reviews should be considered as a general indicator. That is why we retained all items used in traditional medicine.

(2) Furthermore, since botanists are the main providers of ethno-medicinal information, the ethnomedicinal literature is not documented in a symmetrical manner for both medicinal and botanical aspects (Farnsworth, 1990). The latter also insists on the lack of information about the quantities of materials used and the type of preparation (decoction, infusion, paste...). In addition, crucial information, as for instance the cultural construction of efficacy (Etkin, 1988), diet prescribed with specific medication, complex mixture, etc., are rarely reported.

(3) Plants might be used by local peoples following the properties in relation to health, but the aspect of the plant may also play an important role in the symbolic properties. For instance Watt and Breyer-Brandwick (1962) show that: "Among widely separate tribes in Africa, the abundant clustered fruits suggest the notion of fertility (mimetic magic) and they are used in various ways as a charm to promote conception and to ensure an abundant crop". Besides the morphological plant features, some other aspects might be related to the diversity of uses and conception. In current ethno-botanical literature, many plants seem 'universal', and this may explain the case of Ficus exasperata leaves (Table I) used to cure diseases from the four classes defined previously, in countries from West to East Africa. This result from the indigenous semiology, which implies that various symptoms (that western researchers attribute to various diseases) are all disturbance of one single part of the body and/or mind of a human being (Haxaire, 1999).

(4) Food and medicine often overlap in traditional societies (Hugh-Jones, 1993; Motte-Florac et al., 1996) or at least health benefits are supposed for various food, herbs and spices.

(5) Even though the organoleptic characteristics of a plant are culturally interpreted, taste perception may be a major clue for specific choice. Bitterness might be an efficient indicator of bioactive compounds. For instance, treatments based on bitter substances are known in many traditional medicines, and appear to have a peculiar therapeutic relevance. Among the Gbaya, in Central Africa, bitterness of Solanum nigrum, is considered as strengthening the body (a bitter body, pang te, means a vigorous body) and a decoction of the most bitter part of cassava is used to wash children suffering from chickenpox (Haxaire, 1979). In Ivory Coast, for the Gouro of Zuénoula bitter plants are used to cure malaria and the bitter sauces of eggplants is used as fortifying mixture (Haxaire, unpublished data). The possible rationale between these practices may reside in the fact that 'bitter' substances are usually rich in bioactive compounds such as alkaloids (Bruneton, 1993).

Some criteria of selection for medicinal properties of a plant could be shared by humans and chimpanzees such as taste, smell or texture of the items (Krief, 2004). They are probably rooted in the history of early human beings (Johns, 1999; Huffman, 2001). But today utilizations based on symbolic representation sometimes muddled the issue. Thus, apes behaviour might be easier to decrypt than traditional pharmacopoeia in human societies. 
4. 3. How and why does zoopharmacognosy based on great apes provide novel help in drugs discovery?

Given the large number of known higher plant species (between 250,000 and 500,000), of which only $5 \%$ to $15 \%$ have been systematically investigated for the presence of bioactive compounds (Cragg et al., 1997), there is a need to elaborate an efficient strategy for successful screening. Beside traditional means of flora investigation - ethno-medicine, chemo-taxonomy, systematic screening - apes behaviour observation could be a complementary source of information for targeting plants with bioactive properties.

Taste and texture perception of an item that are important factors in the selection of the plants eaten by chimpanzees may change in relation to physiological condition (Krief, 2004). Observations of behavioural changes in relation to sickness or any physiological troubles and physical properties of the plant have determined our choice of the plant screened. Biological properties have been demonstrated for plant parts eaten by chimpanzees (Table II), such as the anti-ulcerogenic and digestive effects of Ficus exasperata also shown in vivo (Akah et al., 1998). The bristly leaves of this species are actually used for both mechanical and chemical properties by local peoples, i.e. against stomach aches and digestive troubles in a large area including five countries, and for rubbing the skin in three countries (table I). Rubia cordifolia and Ficus asperifolia are other species with bristly leaf surface used as medicine and ingested by chimpanzees. Leaf swallowing behaviour was recorded for $R$. cordifolia and F. exasperata (Wrangham, 1995; Huffman, 1997) and Wrangham (1995) proposes that leaf swallowing may alleviate abdominal pain caused by intestinal parasites. The chimpanzees may respond to intestinal discomfort caused by worms in ingesting of whole leaves with common property of roughness. This example illustrates the strong similarities in plant selection criteria among humans and chimpanzees and assesses that accurate observations of the 'diet' changes could provide a new dimension to the conventional approach of apes feeding behaviour.

The issue concerning the relationships between individuals cannot be neglected among the factors determining food choices and the actual activity of the compounds ingested. Since each chimpanzee has an accurate perception of the other individuals of their group and is able to understand their purposes (de Waal, 1982), unconscious signals between various individuals (especially between a young chimpanzee and its mother) might influence either the pleasantness of the taste, or the activity of the compounds ingested in a similar way that, for humans, the relationships between a doctor and his patient can improve the efficiency of a medicine. This phenomenon, described as the 'placebo effect' (Lachaux and Lemoine, 1988), must not be excluded as a possible factor contributing to the efficiency of some of the plants selectively eaten by sick chimpanzees, when a young accompanies its mother. Nevertheless more information is needed because up to now, observations described that young try the plants used by their sick mothers, when the young themselves are healthy and there is no evidence that mothers influence young to take certain plants or take these plants themselves too while healthy so that sick infant will take them and get better (Huffman, pers. comm.). In the context of an experimental study about leaf swallowing in captive chimpanzees, Huffman and Hirata (2004) underline that inter-individual social networks and social tolerance may be important factor in the transmission of this self-medicative behaviour. Moreover, regional differences in plant selection have been pointed out, that might be related to traditional use of plants rather than to species availability (Goodall, 1986). For instance, whereas some items were available during the study period at two study sites in Uganda, their consumption by the chimpanzees was observed only in one site (Pebsworth et al., in prep). Among those items, Acanthus pubescens flowers showing antimicrobial properties (Krief, 2003) were consumed in Budongo community whereas Kanyawara chimpanzees ate only stems and have never been reported eating the flowers. Similar inter-site variations have been observed for non-seasonal item such as bark of Albizia grandibracteata and Markhamia platycalyx, which are only consumed in Kanyawara whereas species are present in Budongo. Both tradition and differences in plant chemistry may play a role in the unique "medicinal culture" found at each site (Pebsworth et al., in prep). More extensive investigations on the health state of chimpanzees would be necessary to clarify the issue of a potential « medicinal culture » among chimpanzee populations.

Finally, although the observer of chimpanzees needs to categorize an individual as sick according to symptoms defined by western veterinary medicine, observations of the chimpanzees in the field may avoid some bias of interpretations from various investigators in ethnopharmacology. Fresh plant parts are ingested 
by chimpanzees and no process such as heating or fermentation may damage natural compounds. Nevertheless association of plants, or consumption of plants with meat, honey or soils would be interesting to investigate because constituents combination may influence the physiological effects of plants. Etkin \& Ross (1991) highlighted the interactions between phytochemicals such as antibiotics antagonized by pectic materials occurring in Citrus sp. or hallucinogenic tryptamines of Psychotria sp. potentiated by Banisteriopsis sp.

Accordingly, chimpanzees are a good model for human pathology and physiology, but, for obvious ethical reasons, they should not be used for medical research and experimentation. The behaviour when individual is sick, the interactions between relatives and comparison between communities 'traditions' should be investigated to provide better knowledge of their use of medicinal plants. Presently, their natural setting, where observations are carried on, can be considered as a kind of 'open laboratory': whatever the mechanism involved in the selection of food plants with bioactive properties by a great ape, this survey confirms that further studies in this field can spin a new leading thread, completing the other approaches to select plants for biomedical research.

\section{Acknowledgements}

We are grateful to the Uganda Wildlife Authority and to the Uganda National Council for Science and Technology for permission to work in the Kibale National Park. SK wishes to give her sincere thanks to Richard Wrangham, director of the Kibale Chimpanzee Project for his support in conducting the study in Kanyawara and providing data and Thierry Sévenet for important help and encouragement during the phytochemical survey. For identification of plant specimens, we deeply thank Annette Hladik and Lucile Allorge. Makerere University Biological Field Station provided facilities and we are thankful to John Kasenene and Gilbert Isabirye-Basuta for their collaboration in the fieldwork. For their invaluable assistance in the fieldwork, SK expresses her sincere gratitude to Jean-Michel Krief, the late Donor Muhangyi, Francis Mugurusi, Christopher Katongole, Christopher Muruuli, Peter Tuhairwe, John Barwogeza, Moses Musana, Kim Duffy and Katie Pieta. Acknowledgements for funding are due to Centre National de la Recherche Scientifique and Muséum National d'Histoire Naturelle, France.

\section{References}

A.C.C.T., 1984. Médecine traditionnelle et pharmacopée- Contribution aux études ethnobotaniques et floristiques au Gabon. Rapport de l'A.C.C.T., Paris, p. 294.

Akah P. A., Orisakwe O. E., Gamaniel K. S., Shittu A., 1998. Evaluation of Nigerian traditional medicines: II. Effects of some Nigerian folk remedies on peptic ulcer. Journal of Ethnopharmacology 62, 2, 123-127.

Ake Assi, L., Abeye, J., Guinko, S., Giguet, R., Bangavou, Y., 1981. Contribution à l'identification et au recensement des plantes utilisées dans la médecine traditionnelle et la pharmacopée en République Centrafricaine. Rapport de l'A.C.C.T., Paris, p. 139.

Ake-Assi, Y.A., 1992. Contribution au recensement des espèces végétales utilisées traditionnellement sur le plan zootechnique et vétérinaire en Afrique de l'Ouest. Thèse de doctorat (Sc. Vétérinaires), Lyon, Université Claude Bernard, p. 220.

Augé, M., 1986. L'anthropologie de la maladie, l'Homme, XXVI, 1-2, p. 81-90.

Baerts, M., Lehmann, J., 2002. L'utilisation de quelques plantes en médecine traditionnelle et vétérinaire en Afrique subsaharienne. Website "Prelude" http://www.preludedb.be.tf

Baerts, M. , Lehmann J., 1991. Plantes médicinales vétérinaires de la région des crêtes Zaïre-Nil au Burundi.Musée royal de l'Afrique centrale, Tervuren. Ann. Sc. Eco. Vol. 21, 133 p.

Baker, M., 1996. Fur rubbing : use of medicinal plants by capucins monkeys (Cebus capucinus). American Journal of Primatology 38, 263-270.

Balagizi Karhagomba, I. , Ntumba Kayembe, F., 1998. Plantes utilisées dans le traitement des helminthoses gastro-intestinales des petits ruminants dans le groupement d'Irhambi-Katana (Région du Bushi, Province du Sud-Kivu, Rép. Dém. du Congo).Recherches africaines n¹, 90 - 99, 1 juillet 1998.

Bally, P.R.O., 1937. Native medicinal and poisonous plants of East Africa. Kew Bulletin 1, 10 - 25. 
Barnish, G., Samai S.K., 1992. Some medicinal plant recipes of the Mende, Sierra Leone. Medical research council laboratory P.O.Box 81, Bo, Sierra Leone , 96 p., SLADEA Publication Kew 633.88 (10.2)

Bost, R., 1961. Pharmacopée malgache. Mémoire de l'Institut scientifique de Madagascar, série B, Tome 10, Fasc. 2, 159 - 234.

Bouquet, A., 1969. Féticheurs et médecines traditionnelles du Congo (Brazzaville). Mémoire O.R.S.T.O.M

Bouquet, A., Debray, M., 1974. Plantes médicinales de la Côte d'Ivoire. Travaux et Documents de l' O.R.S.T.O.M., Paris, n 32, p. 232.

Bruneton, J., 1993. Pharmacognosie, phytochimie, plantes médicinales. Technique et documentation Lavoisier, Paris, p. 915.

Carter, C. A., Gray, E.A., Schneider, T. L., Lovett, C. M., Jr., Scott, L., Messer, A. C., Richardson, D. P., 1997. Toxicarioside B and toxicarioside C, new cardenolides isolated from Antiaris toxicaria latex-derived dart poison. Tetrahedron 53, 50, 16959-16968.

Clark, L., Russel Masson, J., 1985. Use of nest material as insecticidal and anti-pathogenic agents by the European starling. Oecologia 67, 169-176.

Clark, L., Russel Masson, J., 1988. Effect of biologically active plants used as nest material and the derived benefits to starling nestlings. Oecologia 77, 174-180.

Conklin-Brittain, N.L., Wrangham, R.W., 1994. The values of figs to a hind-gut fermenting frugivore : a nutritional analysis. Biochemical Systematics and Ecology 22 (2), 137-151.

Cousins, D., Huffman, M.A., 2002. Medicinal properties in the diet of gorillas- an ethnopharmacological evaluation. African Study Monographs 23:65-89.

Cragg, G.M., Newman, D.J., Snader, K.M., 1997. Natural products in drug discovery and development. Journal of Natural Products, 60, 52-60.

Curasson, M.G., 1938. Les plantes de l'Afrique occidentale considérées par les indigènes comme galactologues. Bulletin des services zootechniques et des épizooties de l'Afrique Occidentale Française 1, 1, 13- 16.

Danbury, T.C., Weeks, C.A., Chambers, J.P., Waterman-Pearson, A.E., Kestin, S.C., 2000. Self-selection of the analgesic drug carprofen by lame broiler chickens. Veterinary Record March, 11, 2000, 307-311.

de Waal, F., 1982. Chimpanzee Politics : power and sex among the Apes. Harper and Row, New York.

Defour, G., 1994. Plantes médicinales traditionnelles au Kivu (République du Zaïre). Documentation du sous-réseau Prélude.

Etkin, N.L., 1981. A Hausa herbal pharmacopoeia : biomedical evaluation of commonly used plant medicines. Journal Ethnopharmacology 4, 75-98.

Etkin, N.L., 1988. «Cultural construction of efficacy» in S. Van der Geest, S.R. Whythe, (Eds), The context of Medicines in developing countries, Reider Publishers Dordrecht, Holland, pp. 299-236.

Etkin, N.L., Ross, P.J., 1982. Food as medicine and medicine as food. An adaptative framework for the interpretation of plant utiliszation among the Hausa of Northern Nigeria. Soc. Sci. Med. 16, 1559-1573.

Etkin, N.L., Ross, P.J., 1983. Malaria, medicine and meals : plant use among the Haussa and its impact on disease. In : L. Romanucci-Ross, D.E. Moerman, L.R. Tancredi (Eds.), the Anthropology of medicine : from culture to method, Praeger, New York, pp. 231-259.

Etkin, N.L., Ross, P.J., 1991. Should we set a place for diet in ethnopharmacology? Journal of Ethnopharmacology 32, 25-36.

Farnsworth, N.R., 1990. The role of ethnopharmacology in drug development. Ciba foundation Symposium. In : Wiley and Sons (Ed.), Bioactive compounds from plants, pp. 2-11.

Farnsworth, N.R., Akerele, O., Bingel, A.S., Soejarto, D.D., Guo, Z.G., 1985. Medicinal plants in therapy. Bulletin WHO 63, 965-981.

Fauth, P.T., Krementz, D.G., Hines, J.E., 1991. Ectoparasitism and the role of green nesting material in the European starling. Oecologia 88, 22-29.

Fellows, L.E., 1992. Pharmaceuticals from traditional medicinal plants and others : future prospects. In : J.D. Coombes (Ed), New drugs from natural sources, IBC technical services LTD, London.

Gbile, Z.O., Adeyemi, F.A., Odewo, T.K., 1990. Nigerian flora and its pharmaceutical potential $n^{\circ} 3$. Mitteilungen aus dem Institut für Allgemeine Botanik, Hamburg 23b, pp. 1033- 1038. 
Gillet, J., Paque E., 1910. Plantes principales de la région de Kisantu. Annales du Musée Royal du Congo Belge sér. 5, 4, 1, p. 120.

Glander, K.E., 1982. The impact of secondary compounds on primate feeding behavior. Yearbook of Physical Anthropology 25, 1-18.

Goodall, J., 1986. The chimpanzee of Gombe. Patterns of behaviour. The Belknap Press of Harvard University Press, Cambridge, Mass., p. 673.

Gwinner, H., Oltrogge, M., Trost, L., Nienaber, U., 2000. Green plants in starling nests : effects on nestlings. Animal Behaviour 59, 301-309.

Harjula, R., 1980. Mirau and his practice. A study of the ethnomedicinal repertoire of a tanzanian herbalist. Institut for cultural research, University of Turku, Finland, p. 224, Tri-Med Books LTD, London.

Haxaire C., 1979. Phytothérapie et médecine familiale chez les

Gbaya -Kara (RCA). Thèse de Doctorat de l'Université des Sciences et Techniques du Languedoc, Académie de Montpellier.

Haxaire, C., 1996. Le vin de palme et la noix de kola: nourritures paradoxales, médiateurs de la communication avec les dieux. In : C.M. Hladik, A. Hladik, H. Pagezy, O.F. Linares, G.J.A. Koppert, A. Froment (Eds.), L'alimentation en forêt tropicale : interactions bioculturelles et perspectives de développement, UNESCO, Paris, pp. 923-938.

Haxaire, C., 1999. Remèdes de jouvence, remèdes de femme. In : A. Guerci (Ed.), Incontri tra medicine, Erga, Genova, pp. 199-216.

Heine, B., König C., 1988. Plant concepts and plant use. An ethnobotanical survey of the semi-arid and arid lands of East Africa. Part 2: Plants of the So (Uganda).142 p., Band Kolner Beiträge zur Entwicklungsländerforschung / Cologne Development Studies Verlag breitenbach Publishers, Saarbrücken, Fort Lauderdale.

Helman, C. G., 1981. «'tonic', 'fuel' and 'food' : social and symbolic aspects of long term use of psychotropic drugs. Social Sciences and Medicine 158, 521-533.

Hill M, Giacosa, A., 1992. The Mediterranean diet (Editorial). European Journal of Cancer Prevention 1:339-340.

Hladik, C.M., 1977a. A comparative study of feeding strategies of two sympatric species of leafmonkeys: Presbytis senex and Presbytis entellus. In : T.H. Clutton-Brock (Ed), Primate Ecology : studies of feeding and ranging behaviour in lemurs, monkeys and apes, New-York Academic Press, New-York, pp. 324-353.

Hladik, C.M., 1977b. Chimpanzees of Gabon and chimpanzees of Gombe : some comparative data on the diet. In : T.H. Clutton-Brock (Ed), Primate Ecology : studies of feeding and ranging behaviour in lemurs, monkeys and apes, New-York Academic Press, New-York, pp. 481-501.

Hladik, C.M., Simmen, B., 1996. Taste perception and feeding behavior in non-human primates and human populations. Evolutionary Anthropology 5, 58-71.

Holmstedt, B., 1991. Historical perspectives and future of ethnopharmacology. Journal of Ethnopharmacology 32, 7-24.

Huffman, M.A., 1997. Current evidence for self-medication in primates: a multidisciplinary perspective. Yearbook of Physical Anthropology 40, 171-200.

Huffman, M.A., 2001. Self-medicative behavior in the African Great : An evolutionary perspective into the origins of human traditional Medicine. Bioscience 51, 8, 651-661.

Huffman, M.A., 2003. Animal self-medication and ethnomedicine: exploration and exploitation of the medicinal properties of plants. Proceeding of the Nutritional Society 62: 371-381.

Huffman, M.A., Seifu, M., 1989. Observations of illness and consumption of a possibly medicinal plant Vernonia amygdalina (Del.), by a wild chimpanzee in the Mahale Mountains National Park, Tanzania. Primates 30 (1), 51-63.

Huffman, M. A., Gotoh, S., Izutsu, D., Koshimizu, K., Kalunde, M. S., 1993. Further observations on the use of the medicinal plant, Vernonia amygdalina (Del) by a wild chimpanzee, its possible affect on parasite load, and its phytochemistry. African Study Monographs 14(4), 227-240.

Huffman, M. A., Koshimizu, K., Ohigashi, H., 1996. Ethnobotany and zoopharmacognosy of Vernonia amygdalina, a medicinal plant used by humans and chimpanzees. In: P.D.S. Caligari, D.J.N. Hind (Eds.), Compositae: Biology \& Utilization Vol 2., Kew: The Royal Botanical Gardens, pp. 351-360. 
Huffman, M. A., Ohigashi H., Kawanaka, M., Page, J. E., Kirby G. C., Gasquet, M., Murakami, A., Koshimizu, K., 1998. African great ape self-medication: A new paradigm for treating parasite disease with natural medicines. In : Y. Ebizuka (Ed.), Towards Natural Medicine Research in the 21st Century, Elsevier Science B.V., Amsterdam, pp. 113-123.

Huffman, M.A., Hirata, S., 2004. An experimental study of leaf swallowing in captive chimpanzees: insights into the origin of a self-medicative behavior and the role of social learning. Primates, 113-118.

Hugh-Jones, S., 1993. "Food" and "drugs" in northern Amazonia. In: C.M. Hladik, A. Hladik, O.F. Linares, H. Pagezy, A. Semple and M. Hadley (Eds.), Tropical forests, people and food. Biocultural interactions and applications to development, UNESCO, Paris, pp. 533-548.

Janzen, D.H., 1978. Complication in interpreting the chemical defenses of trees against tropical arboreal plant-eating vertebrates. In G.G. Montgomery (Ed.), The ecology of arboreal folivores, Smithsonian Institution Press, Washington D.C., pp 73-84.

Johns, T., 1999. The chemical ecology of human ingestive behaviors. Annual Review of Anthropology 28, 27-50.

Kalanda, K., Omasombo, W. D., 1995. Contribution à la connaissance des plantes médicinales du Haut Zaïre: plantes utilisées dans le traitement des maux d'estomac dans la ville de Kisangani. Rev. Méd. Pharm. Afr. Vol. 9, $\mathrm{n}^{\circ} 1,59-69$.

Karban, R., English-Loeb, G., 1997. Tachinid parasitoids affect host plant choice by caterpillars to increase caterpillar survival. Ecology 78 (2), 603-611.

Katende, A.B., Birnie, A., Tengnäs, B.O., 1995. Useful trees and shrubs for Uganda, Identification, propagation and management for agricultural and pastoral communities.Regional Soil Conservation Unit.

Kayonga, A., Habiyaremye, F. X., 1987. Médecine traditionnelle et plantes médicinales rwandaises. Contribution aux études ethnobotaniques de la flore rwandaise. Préfecture de Gisenyi.Univ. Nat. Rwanda, Centre universitaire de recherche sur la pharmacopée et la médecine traditionnelle, Curphametra, inédit, $121 \mathrm{p}$.

Kerharo, J., Adam, J.G., 1974. La pharmacopée sénégalaise traditionnelle. Editions Vigot Frères, Paris, p. 1012.

Kloos, H., McCullough, F.S., 1987. Plants with recognized molluscicidal activity. In K.E. Mott (Ed.), Plant molluscicides. New York.

Kokwaro, J.O., 1976. Medicinal plants of East Africa. East African literature bureau, Kampala, Nairobi, Dar Es Salaam, p. 368.

Krief, S., 2003. Métabolites secondaires des plantes et comportement animal : surveillance sanitaire et observation de l'alimentation de chimpanzés (Pan troglodytes schweinfurthii) en Ouganda. Activités biologiques et étude chimique de plantes consommées. Thèse de Doctorat du MNHN, Paris, p. 375.

Krief, S., Bories, C., Hladik, C.M., 2003. Résultats des examens parasitologiques de selles pratiqués sur une population de chimpanzés sauvages (Pan troglodytes schweinfurthii) d'Ouganda. Bulletin de la Société de Pathologie Exotique 96, 2, 80-82.

Krief, S., 2004. Effets prophylactiques et thérapeutiques de plantes ingérées par les chimpanzés : la notion d' « automédication » chez les chimpanzés. Primatologie 6, 151-172, in press.

Krief , S., Martin, M.-T., Grellier, P., Kasenene, J., Sévenet, T., 2004. Novel antimalarial compounds isolated in a survey of self-medicative behavior of wild chimpanzees in Uganda. Antimicrobial Agents and Chemotherapy 48 (8), 3196-3199.

Krief, S., Huffman, M., Sévenet, T., Guillot, J., Bories, C., Hladik, C.M., Wrangham, R.W., 2005. Non-invasive monitoring of the health condition of Pan troglodytes schweinfurthii in the Kibale National Park, Uganda. International Journal of Primatology 26 (2), in press.

Lachaux, B., Lemoine, P., 1988. Placebo, un médicament qui cherche sa vérité. Medsi/mcGraw-Hill, Paris.

Larrat, M., 1939. Médecine et pharmacie indigènes: Trypanosomiases et piroplasmoses. Cited in Baerts and Lehman, 2002.

Maas, A., 1991. Inventaire des produits traditionnels contre la diarrhée des petits ruminants. Enquête dans le département du Mono. Rapport de stage. Direction de la recherche agronomique. Projet de recherche appliquée en milieu réel. République du Bénin, Ministère du développement rural, p. 39. 
Merker, M., 1910. The Masai. Ethnographische Monographie eines ostafrikanischen Semitenvolkes. Tierzucht-und Tierheilkunde, Chapter XVIII, 161 - 179, Dietrich Reimer Verlag, Berlin.

Mesfin, T., Obsa, T., 1994. Ethiopian traditional veterinary practices and their possible contribution to animal production and management. Revue des sciences et techniques de l' Office international des Epizooties $13(2), 417-424$.

Motte-Florac, E., Bahuchet, S., Thomas, J.M.C., Epelboin, A., 1996. Place de l'alimentation dans la thérapeutique des Pygmées Aka de Centrafrique. In : C.M. Hladik, A. Hladik, H. Pagezy, O.F. Linares, G.J.A. Koppert, A. Froment (Eds.), L'alimentation en forêt tropicale : interactions bioculturelles et perspectives de développement, UNESCO, Paris, pp. 835-856.

Ndayitwayeko, A., Ntungwanayo, V., 1978. Contribution à l'étude de plantes médicinales dans la région de Mugamba. (Commune Mugamba). Mémoire de licence, Univ. Burundi, Fac. Sc., p. 129.

Nyakabwa, M., Gapusi, R., 1990. Plantes médicinales utilisées chez les Banyamulenge de Fizi au SudKivu (Zaïre). African study monographs 11, 2, $101-114$.

Oates, J.F., Swain, T., Zantovska, J., 1977. Secondary compounds and food selection by Colobus Monkeys. Biochemical systematics and Ecology 5, 317-321.

Ohigashi H., Huffman, M.A., Izustu, D., Koshimizu, K., Kawanaka, M., Sugiyama, H., Kirby, G.C., Warhust, D.C., Allen, D., Wright, C.W., Phillipson, J.D., Timmon-David, P., Delnas, F., Elias, R., Balansard, G., 1994 . Towards the chemical ecology of medicinal plant use in chimpanzees : the case of Vernonia amygdalina (Del.). A plant used by wild chimpanzees possibly for parasite-related diseases. Journal of Chemical Ecology 20, 541-553.

Ojinnaka, C.M., Okogun, J.I., Okorie, D.A., 1980. Triterpene acids from Myrianthus arboreus. Phytochemistry 19(11), 2482-2483.

Polygenis - Bigendako, M.-J., 1990. Recherches ethnopharmacognosiques sur les plantes utilisées en médecine traditionnelle au Burundi occidental.Thèse de Docteur en sciences, Univ. libre de Bruxelles, Fac. Sc., Lab. de Botanique systématique et de Phytosociologie, p. 352.

Reynolds, V., Reynolds, F., 1965. Chimpanzees of the Budongo forest, In: I. De Vore (Ed.), Primate Behavior, Holt, Rinehart and Winston, New York, pp. 368-424.

Rodman, P.S., 1978. Diets, densities, and distributions of Bornean primates. In: G.G. Montgomery (Ed.), The ecology of arboreal folivores, Smithsonian Institution Press, Washington D.C., pp. 465-478.

Sawyerr, E.S., 1983. Medicinal plants of West Africa.Vol. 1, Solomon Islands, 88 p.

Schaller, G. B., 1963. The mountain gorilla: ecology and behavior. University of Chicago Press, Chicago and London.

Staner, P., Boutique R., 1937. Matériaux pour l'étude des plantes médicinales indigènes du Congo Belge. Mém. Institut royal colonial Belge, Section des Sc. naturelles et médicales, Collection in- $8^{\circ}$, fasc. 6 et dernier, p. 228.

Sugiyama, Y., Koman, J., 1992. The flora of Bossou: its utilization by chimpanzees and humans. African study monographs 13, 3, $127-169$.

Taniguchi, M., Chapya, A., Kubo, I., Nakanishi, K., 1978. Screening of East African plants for antimicrobial activity. Chemical and Pharmaceutical Bulletin 26, 9, 2910-2913.

Testa, J., Kaimba, C., Delmont, J., 1991. Traitement traditionnel des teignes en RCA. Rev. Méd. Pharm. Afr. Vol. 5, n², $51-55$.

Tutin, C.E.G., Fernandez M., 1993. Composition of the diet of chimpanzees and comparison with that of sympatric lowland gorillas in the Lopé Reserve, Gabon. American Journal of Primatology 30, 195-211.

Van Puyvelde, L., D., Geysen, F.X., Ayobangira, E. H., 1985. Screening of medical plants of Rwanda for acaricidal activity. Journal of Ethnopharmacology 13, 209-215.

Watt, J.M., Breyer-Brandwijk, M.G., 1962. Medicinal and poisonous plants of Southern and Eastern Africa. E. \& S. Livingstone LTD, 2nd edition.

Wrangham, R.W., 1977. Feeding behavior of chimpanzees in Gombe National Park, Tanzania. In : T.H. Clutton-Brock (Ed), Primate Ecology : studies of feeding and ranging behaviour in lemurs, monkeys and apes, New-York Academic Press, New-York. p. 631, pp. 503-538.

Wrangham, R.W., 1995. Leaf-swallowing by chimpanzees and its relationship to tapeworm infection. American Journal of Primatology 37, 297-304. 
Wrangham, R.W., Nishida, T., 1983. Aspilia spp. leaves: A puzzle in the feeding behavior of wild chimpanzees. Primates 24, 276-282.

Wrangham R.W., Waterman P.G. 1983. Condensed tannins in fruits eaten by chimpanzees. Biotropica 15 (3), 217-222.

Wrangham, R.W., Conklin, N.L., Chapman, C.A, Hunt, K.D., 1991. The significance of fibrous foods for Kibale Forest chimpanzees. Philosophical Transactions of the Royal Society of London, Series B 334, 171-178.

Wrangham, R.W., McGrew, W.C., de Wall, F.B., Heltne, P.G., 1994. Chimpanzee cultures. Harvard University Press, Mass, p. 424.

Wrangham, R.W., Chapman, C.A., Clark-Arcadi, A.P., Isabirye-Basuta, G., 1996. Social ecology of Kanyawara chimpanzees : implications for understanding the costs of great apes groups. In : W.C. Mc Grew, L. Marchant, T. Nishida (Eds.), Great Apes Societies, Cambridge University Press, p. 328, pp. 45-57. 